\title{
НЕПРОИЗВОДНЫЕ РУССКИЕ ПРЕДЛОГИ В ИСТОРИЧЕСКОЙ ЛЕКСИКОГРАФИИ: ВЕКТОРЫ СЕМАНТИЧЕСКОГО ОСМЫСЛЕНИЯ
}

Цимбалюк Є. В. Непохідні російські прийменники в історичної лексикографії: вектори семантичного осмислення.

У статті вивчається розуміння мовної природи прийменників і омонімічних префіксів у лексикографії XVIII - XIX ст. Аналіз непохідних прийменників в словниках і граматиках XVIII - XIX ст. дозволяє виявити динаміку осмислення семантики прийменників і витоки сучасних лінгвістичних теорій про мовну природу пропозиціональної лексики.

Ключові слова: прийменник, слово-морфема, слово-речення, структурний аналіз, когнітивно-ономасіологічний аналіз, функціональний аналіз.

Цымбалюк Е. В. Непроизводные русские предлоги в исторической лексикографии: векторы семантического осмысления.

В статье изучается понимание языковой природы предлогов и омонимичных префиксов в лексикографии XVIII - XIX вв. Анализ непроизводных предлогов в словарях и грамматиках XVIII - XIX вв. позволяет выявить динамику осмысления 
семантики предлогов и истоки современных лингвистических теорий о языковой природе пропозициональной лексики.

Ключевые слова: предлог, слово-морфема, слово-предложение, структурный анализ, когнитивно-ономасиологический анализ, функциональный анализ.

Tsymbalyuk E. V. The non-derivative Russian prepositions in historical lexicography: vectors of semantic comprehension.

This article studies the understanding of the language nature of prepositions and their prefixes homonymous in the lexicography of XVIII - XIX centuries. The analysis of non-derivative prepositions in dictionaries and grammars of XVIII - XIX centuries reveals the dynamics of understanding the semantics of prepositions and the origins of modern linguistic theories about the nature of the propositional language vocabulary.

Key words: preposition, word-morpheme, word-sentence, structural analysis, cognitive-onomasiological analysis, functional analysis.

Постановка проблемы. В современной лингвистике наблюдается интерес к теориям, изучающим прототипические структуры языка, которые представляют собой семантические универсалии, способные находить реализацию в единицах и конструкциях различных категорий и уровней. Идея обращения к прототипическим значениям языковых знаков свидетельствует об актуальности исторического метода, широко распространенного в XIX веке и позволяющего придать всему анализу очевидный объяснительный характер.

Актуальность изучения проблемы категоризации предложной и префиксальной единиц обусловлена такими общетеоретическими задачами современной лингвистики, как определение связи процессов концептуализации и категоризации действительности, установление системной и функциональной природы элементов языка, выявление особенностей их мотивированности, изучение феномена интеграционных процессов в динамике языкового развития.

Цель работы заключается в выявлении истоков основных положений современных направлений лингвистики в вопросе категоризации непроизводных предлогов и омонимичных им префиксов в отечественном языкознании XVIII-XIX вв. В ходе исследования были поставлены следующие задачи: 1) описать существующие в отечественном языкознании XVIII- нач. XX вв. концепции языковой сущности омонимичных предлогов и префиксов; 2) выявить связь базовых современных лингвистических теорий: структурной, функциональной и когнитивной - с традицией осмысления данной проблемы в эпоху сравнительно-исторического метода. 
С момента появления первых оригинальных грамматик и до сегодняшнего дня в теории отечественного языкознания продолжается обсуждение дискуссионного вопроса по поводу установления языковой природы предлогов. В лексикографии XVIII-XIX вв. обнаруживается проблема смешения дефиниций «предлог» и «префикс», которая выражается в определении префиксальных морфем как обусловленных синтаксической позицией вариативных употреблений предлогов. В академических изданиях «Церковный словарь» П. А. Алексеева (17731779), «Корнесловъ русскаго языка» Ф. И. Шимкевича (1842), «Словарь церковно-славянскаго и русскаго языка, составленный Вторымъ отд女леніемъ Императорской Академіи Наукъ» (1847), «Толковый словарь живаго великорусскаго языка» В. И. Даля (1863-1866), «Матеріалы для словаря древне-русскаго языка» И. И. Срезневского (1893-1912), грамматиках В. Е. Адодурова, К. С. Аксакова, А. А. Барсова, Ф. И. Буслаева, А. Х. Востокова, Н. И. Греча, И. И. Давыдова, Н. Г. Курганова, М. В. Ломоносова, Д. Н. Овсянико-Куликовского выделяются два вида предлогов: «слитный» и «раздельный» [1, с. 128; 5 , с. $141 ; 8$, с. $112 ; 9$, с. $231-232 ; 10$, с. $75 ; 17$, с. 5,$47 ; 19$, с. $58 ; 20$, с. 123 ; 23, с. 649-650; 24, с. 194].

Понимание предлога как единицы и лексического, и словообразовательного уровня языка связано с проблемой установления дефиниции «слово» и отсутствием термина «морфема» в теории русистики эпохи сравнительно-исторического метода. В научной мысли этого периода в качестве наименьшей структурной единицы языка используются три взаимозаменяемых термина: «знаменательный слог» (А. А. Барсов, Н. И. Греч, Н. Г. Курганов, М. В. Ломоносов), «первообразное слово» (А. А. Барсов, А. А. Потебня) и «корень» (А. А. Барсов, Н. И. Греч, Н.Г. Курганов, А. А. Потебня). Термином «знаменательный слог» обозначается «слогъ, способствующій къ образованію словъ» и называющий «н中которыя вещи, дЊянія, и вообще мысли» [9, с. 17; 23, с. 63]. «Первообразным словом» называется непроизводная основа для ряда однокоренных слов или праоснова [22, с. 17-18; 23, с. 64, 96]. Термин «корень» используется в качестве синонима двух вышеуказанных терминов - «знаменательный слог» $[9$, с. 17; 22, с. 19-20] и «первообразное слово» $[17$, с. $5 ; 22$, с. $17 ; 23$, с. 65,$91 ;]$ и, таким образом, является омонимичным. На основании смешения понятий «корень», «слог» и «слово» лексемы, имеющие в своем составе аффиксы, 
традиционно считаются сложными [8, с. 4 ; 10 , с. 38 ; 17, с. 6 ; 19, с. $105 ; 20$, c. 101,$123 ; 23$, с. $63-64,91 ; 24$, с. 167$]$.

Проблема морфемной типологии входящих в структуру лексемы «корней» в языкознании XVIII-XIX вв. обусловлена спецификой решения вопроса о различении слово- и формообразовательных формантов. Так, с одной стороны, грамматики в системе корней выделяют «главные» - собственно корневые морфемы, представляющие собой прототипическую основу слова, и «придаточные» - определяемые современной наукой как «аффиксы» [9, с. 17; 23, с. 65]. При этом А. А. Барсов, А. Х. Востоков, И. И. Давыдов, М. В. Ломоносов, А. С. Шишков не отмечают суффикс как структурную часть слова, классифицируя все стоящие после корня морфемы как «окончаніе» - «ті посльднія буквы», «не им Њющіе точно опредњленнаго знаменованія оть каковыхъ либо словъ заимствованнаго» [8, с. 4; 23, с. 96]. В результате под «придаточными корнями» понимаются исключительно префиксальные морфемы, а термин «приставка» получает широкое толкование и используется для обозначения аффиксов любого типа. Так, во второй половине XIX века, в период зарождения термина «суффиксъ», в труде «Опытъ русской грамматики» (1880) К. С. Аксаков определяет его следующим образом: «суффиксъ - это приставка, <...> не им'юющая прямаго образовательнаго, ни словопроизводнаго значенія» [1, с. 20].

С другой стороны, в связи с тем, что сравнительно-исторический метод основывается на анализе языка через выявление прототипических инвариантов его структурных единиц, в исторической грамматике утверждается точка зрения на происхождение служебных слов из знаменательных, а деривационных и грамматических формантов из лексем [4, с. 198; 21, с. 110-111; 22, с. 17-21]. В трудах А. В. Добиаша, Н. Г. Курганова, А. Л. Погодина, А. А. Потебни слово рассматривается как синтагма, а предлоги, слитные и раздельные, - как древнейшие корни-основы дофлективного периода $[11$, с. $234,238-239 ; 17$, с. 5; 21 с. $73,110-113 ; 22$, с. 20-21]. Понимание предлогов и префиксов как первообразных слов с пространственной обстоятельственной семантикой приводит А.А.Шахматова в работе «Синтаксис русского языка» к выводу об их адвербиальной природе и к определению «префиксов» как отдельного лексико-грамматического разряда слов в составе служебных частей речи [30, с. 504].

Таким образом, в теории русистики XVIII-XIX вв. проблема определения языковой природы префиксальной и предложной единиц выражается в вопросе о «слитном» и «раздельном» написании 
предлогов и решается тремя способами: 1) определением предлога как «слога», формирующего состав морфемной структуры слова либо оформленного в отдельную лексему (В. Е. Адодуров, П. А. Алексеев, Ф. И. Буслаев, М. В. Ломоносов); 2) как «первообразного слова» [непроизводной основы], реализуемого либо на морфемном, либо на синтаксическом ярусе языка (К. С. Аксаков, И. И. Давыдов, А. В. Добиаш, Н. Г. Курганов, А. Л. Погодин, А. А. Шахматов); 3) как «придаточного корня» [аффикса] и слова служебной части речи (А. А. Барсов, А. Х. Востоков, Н. И. Греч, Н. Г. Курганов, А. С. Шишков). Данные представления находят отражение в базовых идеях основных направлений лингвистики XX века - структурном, когнитивном и функциональном, и продолжают быть дискуссионными на настоящем этапе развития отечественной научной мысли.

Понимание предлога как «слога», входящего в состав морфемной структуры слова либо оформленного в отдельную лексему, формирует морфемную концепцию языкового статуса служебного слова. При таком подходе «слово» определяется как минимальная номинативная единица слоговая структура (морфемный комплекс), выражающая лексическое заключенное в «главном, корневом слоге», и категориальное определяющее принципы взаимосвязи с другими словами и содержащееся в «окончании», значения. Данное определение номинативной единицы зарождается в первой трети XIX ст., отражается в трудах К. С. Аксакова, Ф. И. Буслаева, А. Х. Востокова, И. И. Давыдова, А. А. Потебни, Ф. С. Шимкевича, А. С. Шишкова, А. А. Шахматова $[1$, с. $19-20 ; 5$, с. $72-73 ; 8$, с. 4 ; 10 , с. $54 ; 22$, с. $14,20,34$; 30, c. $431-432$; 31, с. XI; 32, с. 262-264] и основывается на идее наличия или отсутствия у лексем парадигмы словоизменения как основного критерия в вопросе разделения частей речи на знаменательные и служебные, бытующей в первых оригинальных грамматиках и словарях, изданных в конце XVIII - начале XIX вв. Так, предлоги в «Церковном словаре» П. А. Алексеева (1815), грамматиках А. А. Барсова (1783-1785) и Императорской российской Академии (1819) трактуются как «нЊизменяемая» или «несклоняемая» часть речи, перед другими частями речи раздельно или слитно употребляемая [2, с. 231-232; 23, с. 648; 24, с. 294]. На основании одноморфемности структуры, фонетической несамостоятельности и функции служить показателями грамматических отношений знаменательных частей речи непроизводные предлоги в работе «Изъ записокъ по русской 
грамматик'» (1874) А. А. Потебни определяются как «слова лишь въ томъ смысль, въ какомъ суффиксы», а в трудах «Опытъ исторической грамматики русскаго языка» (1858) Ф. И. Буслаева и «Опыть общесравнительной грамматики русскаго языка» И. И. Давыдова (1854) как слова, «тождественные окончаніямъ» - суффиксам и флексиям, выражающим грамматические отношения полнозначных слов в предложении вне их морфемной структуры, в связи с чем классифицируются как «формальные, грамматические слова» и «слова формъ» $[5$, с. 45,$98 ; 10$, с. $13,61,259 ; 22$ с. $34-35]$. Таким образом, лексический статус служебных слов признается формальным и омонимичные предлоги-приставки классифицируются как структурные единицы полнозначного слова.

Идея номинативной недостаточности означаемого корневого морфа в связи с его указанием на понятие, не классифицированное в отношении категориального значения, является базовой в построении теории структурной лингвистики, создаваемой в начале XX века и представленной в отечественной лингвистике работами Г. О. Винокура, И.Р. Выхованца, В. М. Русанивского, А. И. Смирницкого, Ф.Ф.Фортунатова и др. Структурное направление продолжает рассматривать омонимичные предлоги и префиксы как синтаксические корреляты и квалифицирует предлоги с точки зрения их словообразовательной членимости. В связи с одноморфемностью структуры непроизводных предлогов, отсутствием у них категориального и лексического значений, парадигмы словоизменения и невозможностью самостоятельной синтаксической реализации структурализм квалифицирует такие единицы как промежуточное образование - «слова-морфемы» («агглютинативные префиксы» или «препозиционные флексии»), находящиеся наряду с аффиксами в составе формообразующих средств языка [6; 7]. Таким образом, природа и функция аффиксов понимаются двояко: одни из них признаются синтетическими, их предназначение - обслуживать сферу морфологического слова, другие - аналитическими, организующими синтагматику слова.

Концепция предлога как «первообразного слова» [непроизводной основы], реализуемого либо на морфемном, либо на синтаксическом ярусе языка, рассматривает полнозначную лексему с позиции вышеизложенной «слоговой теории» служебных слов и морфем - как слоговую синтагму, однако сам «знаменательный слог» определяется не как формирующий структуру полнозначного слова неноминативный знак, а как прототипический корень-основа, 
функционирующий в качестве полнозначных слов в дофлексийном периоде развития языка и представленный на синтетическом этапе морфемами любого типа $[1$, с. $128 ; 11$, с. $234,238-239 ; 21$, с. $73,110-$ 113; 22, с. 20-21]. Морфемы и служебные слова в «словной теории» изучаются либо в словообразовательной структуре слова, либо в составе предложения по выражаемым ими логическим или грамматическим категориям: корневые и префиксальные «корни-основы» признаются реликтами древнейших «слов-понятий», окончания, предлоги и союзы «слов отношений понятий» [10, с. 11-13]. Таким образом, в отличие от термина «слова форм» «слоговой концепции» служебных слов и морфем, отображающего понимание служебных слов как единиц, тождественных словоизменительным окончаниям, термин «слова отношений» «словной концепции» служебных слов и морфем рассматривает выражаемую ими релятивную семантику в качестве категориального значения соответствующих прототипических полнозначных лексем.

В результате обладающая флексией полнозначная лексема в «словной концепции» предлогов-приставок осознается как свернутое предложение, что отражается в грамматиках конца XVIII-XIX вв.

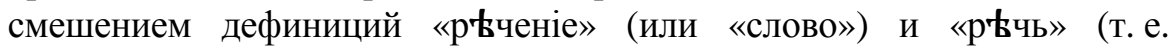
предложение). Так, термин «рьченіе» используется для обозначения следующих понятий: 1) грамматической структуры знаменательного слова, отображающей его лексическое и категориальное значение $[1$, с. 18,$21 ; 10$, с. $11 ; 22$, с. 100]; 2) «дофлексийного корня-основы», или «знаменательного слога» (словообразовательной морфемы) [1, с. 17; 23, с. 63]; 3) словообразовательной структуры знаменательного слова, представленного «наращением слогов» $[17$, с. 1,5 ; 19 , с. 20, 49-50; 23 , с. $63 ; 24$, с. 7-8], вследствие чего слово определяется как предложение или «р'ъчь» $[10$, с. $11 ; 27$, с. 223]. Понимание слова как «свернутого предложения» также отразилось в представлениях языкознания XVIII-XIX о разделах языкознания. Так, в трудах XVIII XIX в грамматике традиционно выделяется два раздела - «этимологія» (или «словообразованіе», «словопроизвожденіе», словопроизведеніе», «словопроизводство») и «синтаксісъ» («словосочиненіе», «р'ьчь») $[8$, c. $1-2,116 ; 9$, c. $1 ; 10$, c. $21 ; 17$, c. $1 ; 23$, c. 90,$153 ; 24$, c. 32 , 197]. Учение о частях речи относится грамматистами либо к «частному разд'大лу этимологіи» как учение о «произведеніи словь по свойству выражаемых ими понятій и чувствованій» [9, с. 1,22], об «ихъ составныхъ частяхъ и измененіяхъ, и распредЊленіи по разрядамъ» $[8$, с. 2] 
(А. А. Барсов, А. Х. Востоков, Н. И. Греч, Н. Г. Курганов, Россійская грамматика 1819 г.), либо к «синтаксису» - как учение о «расположеніи частей ртчи и взаимномъ оныхъ соединеніи» «по ихъ надлежащимъ падежамъ, родамъ, числамъ, лицамъ, временамъ и местамъ» [17, с. 4, 55; 24, с. 197] (А. А. Барсов, Ф. И. Буслаев, А. Х. Востоков, Н. Г. Курганов, Россійская грамматика 1819 г.).

Сами прототипические слова на основании того, что в дофлексийный период развития языка не существовало лексикограмматических категорий, в сравнительно-историческом методе языкознания определяются как «корни безотносительные», означающие «неразложенное воспріятіе, безразличную совокупность д'ятельности или качества и предмета» [22, с. 102-103] и классифицируются как «древнейшие предложения» $[1$, с. $151 ; 10$, с. 11; 22, с. 100; 31, с. ХI]. Так, И. И. Давыдов в работе «Опыть русской грамматики» (1854) отмечает: «Первое умственное сознаніе состоить изь полной мысли, и первое слово челов'Кка - предложеніе» [10, с. 11]. Данное положение истолковывается А. А. Потебней в работе «Изъ записокъ по русской грамматике» (1874) следующим образом: «подъ «предложеніемъ» безсознательно разум'大ется <...> психологическое (не логическое) сужденіе при помощи слова. Первое слово служитъ связью двухъ мысленныхъ единицъ: объясняемой (психологіческий субъектъ) и объясняющей (психологіческий предикать). Такое слово есть представленіе объясняемаго. Сочетаніе двухъ такихъ словь есть представленіе объясняемаго и представленіе объясняющаго безъ всякаго сознанія ихъ отношеній» [22, с. 100]. Таким образом, во второй половине XIX века анализ понятийной структуры слова начинает основываться на выявлении значения пропозициональных компонентов в его словообразовательной структуре.

Предлоги в «словной концепции» служебных слов и морфем понимаются как корни, «изготовленные на скорую руку, чтобы удовлетворить <...> самую примитивную <...> и первую потребность $\langle\ldots\rangle$ в движении человеческой мысли» [11, с. 234], и рассматриваются как свернутые «суждения». Так, в труде «Опыть русской грамматики» (1880) К. С. Аксаков определяет предлог как «корень имени, обнаженный оть его формы, слњдовательно одно содержаніе, значеніе, мысль и уже не имя больє»», корень имени, «который вносить новое понятіе, еще смутно, какъ намекъ, понятіе движенія, движущей силы, силы дъйствующей, обозначившейся уже въ управленіи падежами», и характеризует его уникальную языковую природу способностью «разр'ьшать сферу 
выразившагося въ слов бытія въ покоҺ» [1, с. 150-151]. Проблема определения языкового статуса «слитных» и «раздельных» предлогов решается выявлением выражаемых ими логических или грамматических категорий как актуализации компонентов свернутой предикативной структуры: префиксы характеризуются как формирующие сложное слово «корни» и относятся к разряду «слов-понятий», предлоги в сочетании со словом в падежной форме по выражаемой ими семантике релятивности отождествляются с окончаниями полнозначных слов и классифицируются как древнейшие «слова отношений» [10, с. 11-13, 61, 259]. Таким образом, языковая природа «слитных» и «раздельных» предлогов определяется как корни-основы, способные выражать и лексические, и грамматические категории.

Предложенная в «словной концепции» служебных слов и морфем методология анализа языка находит отражение в принципах когнитивноономасиологического подхода к изучению языка, зародившегося во второй половине XX века и развиваемого в отечественном языкознании в работах Н. Д. Арутюновой, Ю. Д. Апресяна, В. И. Карасика, Е. С. Кубряковой, Е. А. Селивановой, Ю. С. Степанова, В. И. Теркулова и др. Когнитивно-ономасиологический анализ основывается на выявлении в языке ментальных структур, представляющих собой семантические универсалии, способные находить реализацию в единицах различных категорий, уровней и конструкций. В качестве центральной единицы понятийной структуры языка, как и в «словной концепции» служебных слов и морфем сравнительно-исторического языкознания, когнитивистика выбирает морфему - минимальный сигнификативный конструкт в языковом сознании человека [3, с. 161-166]. Проблема функциональной омонимии в когнитивистике решается поиском инварианта исходной и трансформированной единицы - семантикограмматического знака, находящего реализацию в различных грамматических категориях и представляющего сигнификативную взаимосвязь уровней языка. При установлении мотивации развития языкового знака утверждается о когнитивной природе деривации и наличии у нее номинативной функции в связи с выделением и фиксацией словообразовательными средствами новых структур знания, закреплением и объективацией неких концептуальных объединений, рождаемых в актах познания и оценки мира [16, с. 407; 26, с. 70]. Таким образом, для выявления языковых принципов выражения означающего в означаемом когнитивное направление использует методологию теории номинации, или ономасиологии, 
которая заключается в установлении связи значения, подлежащего вербализации, с формой его выражения и в выявлении способов представления сигнификативных составляющих в структуре производного знака $[14, \mathrm{c.} 21-22]$. В связи с этим словообразовательные модели начинают рассматриваться как «формулы регулярной свертки пропозициональной структуры», актуализируемой производными словами [16, с. 412], и утверждается наличие в производном слове таких компонентов пропозиции, как диктум, модус и предикат. Диктум (в терминологии ономасиологии «базис») выражает объективный смысл семантической структуры слова, указывает на его принадлежность к определенному понятийному классу, родовому понятию, играет ведущую роль в его первичной категоризации, определении места в языковой картине мира и в словообразовательной структуре заключается в частеречных формантах. Модус (в теории ономасиологии - «признак») отражает субъективный компонент смысла единицы через референцию содержащихся в семантике диктума разнообразных неактуализированных свойств, сужая, таким образом, исходное значение диктума, и выражается основой лексемы. Предикат является смысловой связкой модуса с диктумом в соотнесенности с моментом коммуникации [13, с. 137-140; 16, с. 196-199]. Таким образом, основной задачей когнитивно-ономасиологического подхода является изучение сигнификативной функции производной единицы и ее роли в смысловой (целостной) структуре языковой единицы с учетом ее зависимости от исходного материала, подвергнувшегося трансформации.

Семантическая структура служебного слова и производных от него деривационных морфем интерпретируется как некая нечленимая сущность - в терминологии Дж. Лакоффа «схема-образ», представляющая собой прототипическое значение слова [18] с пространственной пропозициональной семантикой (М. И. Конюшкевич, Е. С. Кубрякова， Л. Ленгрен， У. Л. Чейф) [12, с. 201; 28, с. 173-174]. Способность непроизводных предлогов обладать пропозициональными значениями - выражением наиболее общих отвлеченных понятий связывается с когнитивной функцией предлогов образовывать понятийный каркас координации пространства.

Ономасиологическое направление, опираясь при анализе понятийного конструкта языкового знака на его словообразовательную структуру, определяет предлоги как древнейшие корни-основы с материально не выраженными флексиями начальной формы [15, c. 11]; в связи с чем отсутствие словообразовательной членимости данных единиц 
трактует как способность в чистом виде выражать базисную прототипическую семантику - некий уникальный, прагматически значимый языковой смысл, выполняющий функцию структурного категоризатора ментальной категории пространства. В аспекте ономасиологической теории наличие у предлога пропозиционального значения при отсутствии словообразовательного членения может свидетельствовать о содержании в его прототипическом базисе первичного «сгустка» пропозициональной семантики, которая у производных слов представлена в виде «свернутой пропозициональной структуры». В связи с чем анализ функциональных омонимов предлог-приставка осуществляется через определение общего прототипа и категориальной семантики уровневых структур языка, в сферы которых он проецируется.

Теории «слоговой» и «словной» природы предлогов-префиксов (структурная и когнитивная концепции) классифицируют единицы языка на основании их морфемной структуры, отображающей категориальное значение. От данных методик установления природы языковых знаков отличается функциональный подход, определяющий предлог и префикс как разноуровневые единицы - «придаточный корень» [аффикс] и слово служебной части речи. Следует обратить внимание на то, что в научных трудах XVIII-XIX вв. не наблюдается последовательного изложения какой-либо концепции языковой природы омонимичных предлоговпрефиксов и в одном издании высказываются различные теории. Так, наряду со структурным подходом сосуществует традиция определения статуса языковых единиц по их назначению в языке, которая берет начало в первых оригинальных грамматиках - «Россійской грамматике» М.В.Ломоносова (1755), «Письмовнике» Н. Г. Курганова (1793), и продолжается в трудах «Ньчто о предлогахъ» А. С. Шишкова (1825), «Практическая русская грамматика» Н. И. Греча (1827), «Русская грамматика» А. Х. Востокова (1831), «Опыть общесравнительной грамматики русского языка» И.И. Давыдова (1854), «Опыть исторической грамматики русскаго языка» Ф. И. Буслаева (1858), «О значеніи формъ русскаго глагола» Н. П. Некрасова (1865) и др. Исходя из морфемной структуры и синтаксической функции непроизводного предлога грамматисты XIX века определяют его языковую природу либо как слово с бесфлективной корневой основой, обладающей релятивной (М. В. Ломоносов, А. С. Шишков), обстоятельственной (Н. Г. Курганов) или совмещающей релятивность и обстоятельственность (И. И. Давыдов, А. Х. Востоков) семантикой, 
либо как слово, грамматическое окончание которого является падежным формантом управляемого имени (Н.И.Греч). Так, М. В. Ломоносов в качестве категориального значения предлогов указывает их грамматическую функцию: «знаменательныя части слова должны имьть между собою соответствіе <...> Къ сему служать особливыя части заменующїя первыхъ другъ къ другу принадлежность, и называются Предлоги» [19, с. 24]; Н. Г. Курганов - понятийную: «сїи частицы называются предлогами по тому, что онь всегда раздыльно и совокупно полагаются предъ прочими частьми рьчи, для означенїя перемњны обстоятельства и дъянїи вещей» [17, с. 47]. И. И. Давыдов, продолжая рассматривать значение предлогов как выразителей обстоятельственной семантики и синтаксических отношений, первое характеризуют как «вещественное», эквивалентное знаменательной лексике, второе - как грамматическое, эквивалентное формантам: «предлоги тождественны съ нарьчіями по означенію пространственнаго отношенія дьйствія, а съ падежами по означенію отношенія направленія» [10, с. 259]. Подобного мнения о языковой сущности предлогов придерживается и А. Х. Востоков: «отдельно поставленные предъ именами и мъстоименіями, предлоги служатъ въ помощь падежамъ, показывая отношенія мъжду предметамі, <...> слитно съ глаголами, предлоги показываютъ направленіе дьйствій, начало и конецъ оныхъ» [8, с. 112]. Определение «слитных» и «раздельных» предлогов как разноуровневых единиц - слов и их структурных компонентов - наиболее наглядно отображено в «Практической русской грамматике» Н. И. Греча: «Предлоги имњють въ язык' двоякое назначеніе: во первыхъ, употребляются оные, какъ корни придаточные предъидущіе, въ образованіи разныхъ частей рьчи <...>; во-вторыхъ, поставляются оные, какъ частицы ръчи <...> для означенія отношеній, существующіхъ между предметами и качествами или д Һйствіями, кои выражаются сими словами» [9, с. 232].

$\mathrm{B}$ XX веке функциональным направлением лингвистики в качестве дифференциальных признаков слова предлагается считать наличие у него категориального значения, морфемной структуры, парадигмы изменения и синтаксической функцией [25, с. 457], в связи с чем предлоги на основании обладания релятивной семантикой, возможности занимать определенную синтаксическую позицию и влиять на содержание и форму синтаксических единиц - от словоформы и словосочетания до самого предложения и речи в целом - были отнесены 
к классу слов (В. А. Богородицкий, Й. Вахек, С. И. Карцевский). При этом, как и в языковедении XVIII-XIX вв., встает проблема определения категориального значения предлогов. Так, одни лингвисты в силу того, что звуковая оболочка служебных слов не способна отражать предмет или явление действительности, отрицают существование у предлогов лексического значения как «вещественного», материального содержания и признают наличие у них ослабленного семантического наполнения, выражающего релятивность (В.В. Виноградов, Ю.С. Маслов, Е. Н. Сидоренко, А. А. Реформатский). Другие расширяют само понятие «лексического значения» до способности иметь постоянное содержание, соотносимое с элементом внеязыковой действительности (А. В. Бондарко, В.Г. Гак, Е.С. Кубрякова), и под лексическим значением предлогов предлагают понимать «семантические элементы, связанные с конкретизацией обстоятельственных отношений» [29, с. 424], а выражаемую ими падежную семантику считать их грамматическим значением (Н. П. Колесников, А. Н. Тихонов, С. В. Чесноков, Н. М. Шанский).

Приставка в функциональной школе рассматривается как модифицирующая корневую морфему структурная единица слова (О. С. Ахманова, Д. Э. Розенталь, Г. П. Цыганенко). В результате случаи употребления одного звукового комплекса и в качестве предлога и в качестве префикса определяются как явления межуровневой функциональной омонимии (В. В. Бабайцева, Е. П. Калечиц, О. М. Ким, В. Н. Мигирин).

Выводы. В ходе исследования дефиниций непроизводных предлогов в словарях и грамматиках XVIII-XIX вв. была выявлена динамика осмысления семантики предлогов как «знаменательных слогов» [морфем], формирующих состав морфемной структуры слова либо оформленных в отдельную лексему; как «первообразных слов» [непроизводных основ], реализуемых либо на морфемном, либо на синтаксическом ярусе языка; как «придаточных корней» [аффиксов] и слов служебной части речи. Понимание непроизводного служебного слова как «слога», входящего в состав морфемной структуры слова либо оформленного в отдельную лексему, формирует морфемную концепцию языкового статуса предлога, которая заключается в определении предлогов как единиц, тождественных падежным окончаниям, «формальных слов» или «слов форм». «Слоговая концепция» языковой природы предлогов в XX веке получает развитие в структурном направлении лингвистики, классифицирующем предлоги с точки зрения отсутствия у них словообразовательной членимости как промежуточное 
образование - «слова-морфемы», находящиеся наряду с аффиксами в составе формообразующих средств языка. В концепции предлогов как «первообразных слов» [непроизводных основ], реализуемых либо на морфемном, либо на синтаксическом ярусе языка, полнозначная лексема осознается свернутым предложением, словообразовательные морфемы которой являются реликтами древнейших «слов-понятий», а формообразующие - «слов отношений понятий». Предлоги на основании того, что в дофлексийный период развития языка не существовало лексико-грамматических категорий, определяются как корни-основы, содержащие нерасчлененное суждение. Данные идеи находят отражение в современной когнитивно-ономасиологической концепции служебных слов, которая заключается в установлении связи значения, подлежащего вербализации, с формой его выражения и определяет непроизводные служебные слова свернутыми пропозициональными структурами. Определение предлога как «придаточного корня» [аффикса] и слова служебной части речи отражает функциональный подход к изучению языковых единиц, основанный на установлении их назначения в языке.

Таким образом, представления сравнительно-исторического метода о языковой природе предлогов находят отражение в базовых идеях основных направлений лингвистики XX века - структурном, когнитивном и функциональном, и продолжают быть дискуссионными на настоящем этапе развития отечественной научной мысли.

\section{Литература}

1. Аксаковь К. С. Полное собраніе сочиненій : [в 3-х т.] / Константинь Серг'вевичь Аксаковь. - Москва : Университетская типографія (М. Катковъ), на Страстномь бульваръ, 1861-1880. - Т. 3 : Сочиненія филологическія, Ч. 2 : Опыть русской грамматики. - 1880. [XXXVI], [VIII], [II], 479, [151] c.

2. Алекскевь П.А. Церковный словарь или истолкованіе реченій славенскихъ древнихъ, такожь иноязычныхъ, безъ перевода положенныхъ, въ священномъ писаніи и других церковныхъ книгахъ : [в 4-х ч.] / сочиненный Московскаго Архангельскаго Собора Протопресвvтеромъ и Императорско Россійской Академіи Членомь Петромъ Алексъевичемъ Алексъевымъ. - Вновь исправленный и противу втораго издания весьма многими словами и речениями дополненный. - Москва : Сунодальная типографія, 1816. Ч. 3 : От Н до С. -329 с.

3. Блумфильд Л. Язык / Леонард Блумфильд ; [пер. с английского Е. С. Кубряковой, В. П. Мурат; под ред. и с предисловием М. М. Гухман]. - М. : Прогресс, 1968. - 608 с.

4. Богородицкий В. А. Общий курс русской грамматики : из университетских чтений / Василий Алексеевич Богородицкий. - [5-е изд., перераб.]. - М.-Л. : Соцэкгиз, 1935. -223 с. 
5. Буслаевъ Ө. И. Опытъ исторической грамматики русскаго языка : учебное пособіе для преподавателей : [Ч. 1-2] / Өедоръ Ивановичъ Буслаевъ. - Москва : Университетская типографія, 1858. - 2 т. - (Учебные руководства для военноучебных заведений). - Ч. 1 : Этимологія. - [XL], 244, [12] с. - Ч. 2 : Синтаксисъ. [X], 428, [2] c.

6. Виноградов В. В. Русский язык : (Грамматическое учение о слове) : [учеб. пособие для вузов по спец. «Русский язык и литература»] / Виктор Владимирович Виноградов. - [3-е изд., испр.]. - М. : Высшая школа, 1986. - 559 с.

7. Вихованець I. Р. Прийменникова система української мови / Іван Романович Вихованець - К. : Наук. думка, 1980. - 287 с.

8. Востоковъ А. Х. Русская грамматика Александра Востокова, по начертанію его же сокращенной грамматики полнъе изложенная / Александръ Христофоровичъ Востоковъ. Двънадцатое изданіе. - Санктпетербургъ : Императорская Академія Наукъ, 1874. - [ХII], 201, [4] c.

9. Гречъ Н. И. Практическая русская грамматика, изданная Николаемъ Гречемъ / Николай Ивановичъ Гречъ. - Санктпетербургъ : Типографія Императорскаго Санктпетербургскаго Воспитательнаго Дома, 1827. - [VIII], 578, [1] с.

10. Давыдовъ И. И. Опыть общесравнительной грамматики русскаго языка / [Второъ отдыленіе Императорской Академіи Наукъ, под ред. Академика Ивана Ивановича Давыдова]. - Третіе изданіе. - Санктпетербургъ : Императорская Академія Наукъ, 1854. - [LXII], 512 с.

11. Добіашъ А. В. Опытъ семасиологіи частей ръчи и ихъ формъ на почвъ греческаго языка / Антонъ Вячеславовичъ Добиашъ. - Прага, 1897. - 286 с.

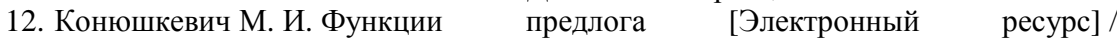
М. И. Конюшкевич // Функціонально-комунікативні аспекти граматики і тексту : збірник наукових праць, присвячений ювілею професора А. П. Загнітка. - Донецьк : ДонНУ, 2004. - С. 196-202. - Режим доступа: http://mova.dn.ua/content/view/34/8/1/3/

13. Краткий словарь когнитивных терминов / [В. З. Демьянков, Е. С. Кубрякова, Л. Г. Лузина, Ю. Г. Панкрац; под общ. ред. Е. С. Кубряковой]. - М. : Филологический фак-т МГУ им. М. В. Ломоносова, 1997. - 245 с.

14. Кубрякова Е. С. Ономасиологические характеристики комплексных единиц словообразовательной системы / Е. С. Кубрякова // Актуальные проблемы русского словообразования : сборник научных статей / [Отв. ред. А. Н. Тихонов]. - Ташкент : Укитувчи, 1982. - С. 21-25.

15. Кубрякова Е. С. Части речи в ономасиологическом освещении / Елена Самойловна Кубрякова - М. : Наука, 1978. - 115 с.

16. Кубрякова Е. С. Язык и знание : На пути получения знаний о языке. Части речи с когнитивной точки зрения. Роль языка в познании мира / Елена Самойловна Кубрякова. - М. : Языки славянской культуры, 2004. - 560 с.

17. Кургановъ Н. Г. Письмовникъ, содержащій въ себъ науку россійскаго языка со многимъ присовокупленіем разнаго учебнаго и полезнозабавнаго вещесловія [Текст] / составленный Профессоромъ и Кавалеромъ Николаемъ Гавриловичемъ Кургановымъ. Пятое изданїе. - Санктпетербургъ : Императорская Академїя Наукъ, 1793. - Ч. 1. - [Х], 394 c. 
18. Лакофф Дж. Женщины, огонь и опасные вещи : что категории языка говорят нам о мышлении / Джордж Лакофф ; [пер. с английского И. Б. Шатуновского]. - М. : Языки славнской культуры, 2004. - 792 с.

19. Ломоносовъ М. В. Россійская грамматика Михайла Васильевича Ломоносова [Текст] / Михайло Васильевичъ Ломоносовъ. - Санктпетербургъ : Императорская Академія Наукъ, 1755. - 210, [3] с.

20. Первая русская грамматика на родном языке : (Доломоносовский период отечественной русистики) [Текст] / Адодуров Василий Евдокимович; [под ред. и с предисловием Б. А. Успенского]. - М. : Наука. 1975. - 232, [1] с.

21. Погодинъ А. Л. Сльды корней-основъ въ славянскихъ языкахъ / Александръ Львовичь Погодинъ. - Варшава: Типографія Варшавскаго учебнаго округа, 1903. - 310 с.

22. Потебня А. А. Изъ записокъ по русской грамматик' [в 2-х ч.] / Александръ Афанасиевичъ Потебня. - Воронежъ : Типографія Н. Д. Гольдштейнъ, 1874. - Ч. I : Введение. - 157, [4] с.

23. Российская грамматика Антона Алексеевича Барсова [Текст] / Антон Алесеевич Барсов; [под ред. и с предисловием Б. А. Успенского]. - М. : Изд-во Московского университета, 1981. - 776 с.

24. Россійская грамматика сочиненная Императорскою Россійскою Академіею / Императорская Россійская Академія. - Третье изданіе. - Санктпетербургъ : Типографія Императорской Россійской Академіи, 1819. - [IV], [III], 273 , [1] с.

25. Русская грамматика : [в 2-х т.]. - М. : Наука, 1980. - Т. 1 : Фонетика. Фонология. Ударение. Интонация. Введение в морфемику. Словообразование. Морфология / [редкол. Шведова Н. Ю. (гл. ред.) и др.]. - 1980. - 783 с.

26. Селиванова Е. А. Когнитивно-ономасиологический аспект фразеологического семиозиса / Е.А.Селиванова // Фразеологизм в тексте и текст во фразеологизме : Четвертые Жуковские чтения) : материалы Международного научного симпозиума (Великий Новгород, 4-6 мая 2009 г.) / [Отв. ред. В. И. Макаров]. - Великий Новгород : НовГУ им. Ярослава Мудрого, 2009. - С. 69-72.

27. Срезневскій И. И. Матеріалы для словаря древне-русскаго языка по письменнымъ памятникамъ : [в 3-х т.] / [Отд中леніе русскаго языка и словесности Императорской Академіи Наукъ, под ред. Измаила Ивановича Срезневского]. - Санктпетербургъ: Типографія Императорской Академіи Наукъ, 1893-1912. - Т. 3 : Р-А и дополненія. - 1912. - [4], 842, [136], [13] c.

28. Чейф У. Л. Значение и структура языка / Уоллес Л. Чейф. - М. : Прогресс, 1975. - 432 с.

29. Шанский Н. М., Тихонов А. Н. Словообразование и морфология / Н. М. Шанский, А. Н. Тихонов. - М. : Наука, 1981. - 270 с.

30. Шахматов А. А. Синтаксис русского языка / Алексей Александрович Шахматов. - [изд-е 2-е]. - Л. : Учпедгиз, 1941. - 620 с.

31. Шимкевичъ Ө. С. Корнесловъ русскаго языка, сравненнаго со всъми главн中ишими славянскими нарьчіями и съ двадцатью четырьмя иностранными языками / Өедоръ Спиридоновичъ Шимкевичъ. - Санктпетербургъ : Императорская Академія наукъ, 1842. Ч. 1. - [XXVI], $160 \mathrm{c}$.

32. Шишковъ А. С. Собраніе сочиненій и переводовъ адмирала Шишкова, Россійской Императорской Академіи Президента и разныхъ ученыхъ обществъ Члена. / Александръ 
Семеновичъ Шишковъ - С. Петербургъ: Типографія Императорской Россійской Академіи, 1825. - Ч. 5. $-416,[3] \mathrm{c}$.

Стаття надійшла до редакції 21.09.2012 p. 